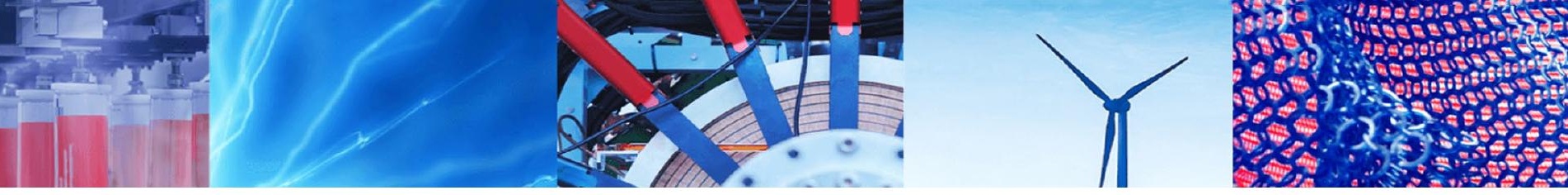

Research Article

\title{
Historic low stand of Great Salt Lake, Utah: I
}

\author{
Mass balance model and origin of the deep brine layer
}

Paul W. Jewell ${ }^{1}$

Received: 29 March 2021 / Accepted: 7 June 2021

Published online: 28 July 2021

(c) The Author(s) $2021 \quad$ OPEN

\begin{abstract}
Great Salt Lake of Utah is among the largest and most ecologically important water bodies in North America. Since the late 1950s, the lake has been divided into two hydrologically distinct water bodies by a rock-fill railroad causeway. Flux through the causeway is driven by two forces: differential surface elevation and differential density between the north and south arms. The south arm features episodic vertical stratification due to the influx of deep, dense brine from the north arm. The source of this brine (a breach, two culverts, or subsurface flow) has been investigated over the past 50 years. Quantification of subsurface water flux through the causeway has been problematic due to the heterogeneous and slowly compacting nature of the causeway fill over time. Between 2008 and 2015, enhanced gauging of various surface inflows and outflows and density measurements made throughout the lake permitted detailed water volume calculations of both lake arms. Results show that during high precipitation years, density-driven, north-to-south flow through the causeway predominates due to freshening of water in the south arm. At other times, south-to-north head gradient driven flow and north-to-south density-driven flow are approximately equal. The model suggests subsurface flux through the causeway is one important driver of the ecologically important deep brine layer in the south arm of the lake over the past 20 years.
\end{abstract}

Keyword limnology · Great Salt Lake · Mass balance model

\section{Introduction}

Saline lakes have long been recognized for their cultural and scientific importance. A common feature of these lakes is distinctive water masses separated by sharp vertical density gradients. Natural examples include the Dead Sea (e.g., [23] and Canadian prairie lakes [21, 22]. Examples of human-caused stratification include Big Soda Lake in the western Great Basin of the U.S. [19, 38], Salton Sea [20] and Mono Lake [15] in California, and the southern arm of Great Salt Lake of the eastern Great Basin [13]. Vertical stratification often leads to anoxic bottom waters with anomalously high metal concentrations (e.g., [32]. Understanding the controls by which these water masses form and disappear is thus a critical question in the field of physical limnology and lacustrine geochemical cycles.

Great Salt Lake in the eastern Great Basin of Utah is the largest closed-basin lake in North America. The lake and surrounding wetlands are important resting places and food resources for migratory water fowl (e.g., [2], as an economic driver for a variety of extractive industries [9], and as a record of climate and paleoclimate [12, 29,47].

During the mid-1950s, a rock-fill railroad causeway was constructed across Great Salt Lake separating the lake into

Paul W. Jewell, paul.jewell@utah.edu |'Department of Geology and Geophysics, University of Utah, Salt Lake City, UT 84112, USA.

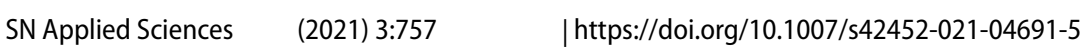


two hydrologically distinct water bodies: the north and south arms (Fig. 1). The only significant water inputs to the north arm of the lake are from precipitation and flux through the causeway. The south arm receives water from precipitation, three major river systems (Bear, Weber, and Jordan), and small secondary streams principally along the eastern edge of the lake. The Jordan River has been extensively engineered into a series of canals, the largest of which (the Goggin) discharges into the southern end of the lake. Lesser components of the Jordan River discharge into the southern end of Farmington Bay. These differences produce significant salinity contrasts between the two lake arms. The south arm is also characterized by a bathymetric high (sill) south of the causeway (Fig. 1).

Mechanisms to mitigate salinity differences between the two arms of the lake have evolved over time. Two, 4.6- $\mathrm{m}$ wide culverts were initially installed to allow boat traffic between the two arms while also permitting significant two-way exchange of water between the arms (Fig. 1). The two culverts often became clogged with debris [49]
Fig. 1 Location and lake bathymetry ( $1 \mathrm{~m}$ contours) of the Great Salt Lake as of 2008 with river inlets, breach and culvert locations, and U.S. Geological Survey sampling localities (squares) and Utah Geological Survey localities (circles). Inputs for the mass balance model are shown in italics. The Jordan River primarily enters the Great Salt Lake through Farmington Bay and the Goggin Drain

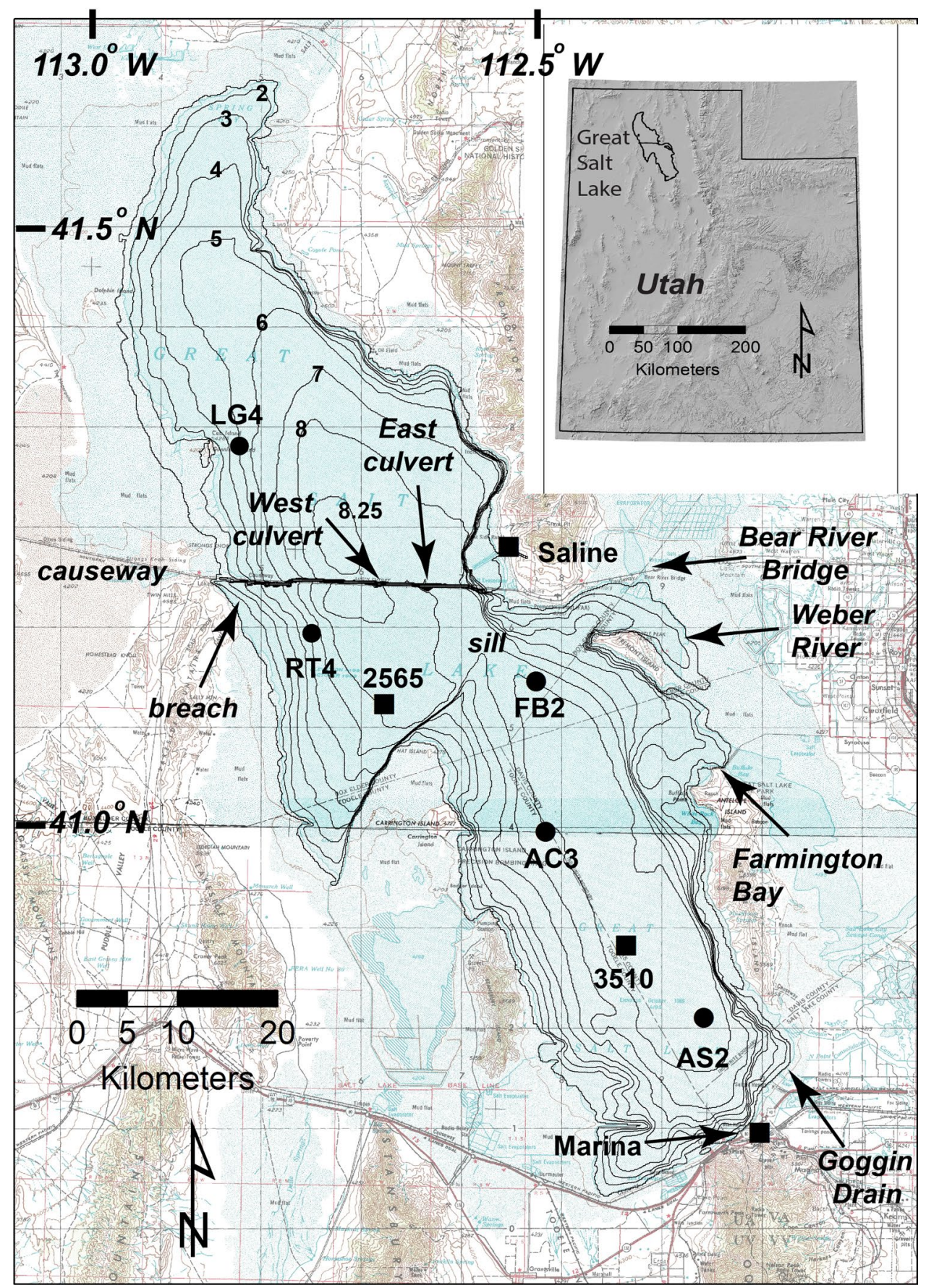


and by 1998 had subsided 2.4-3.3 m below their original elevation [24]. By 2014, the railroad abandoned efforts to keep the culverts open and they were subsequently completely filled in.

Following the historic mid-1980s lake hightstand, a $47 \mathrm{~m}$ breach was constructed and opened in 1984 on the western side of the causeway to facilitate better water exchange between the two lake arms (Fig. 1). However, a drought and historically low lake levels during the 2000s left the breach with minimal water transmission. A wider $55 \mathrm{~m}$ and deeper breach was completed and opened in late 2016 to replace the decommissioned culverts. Quantifying water flux through the breach has proved problematic due to lateral and bottom shear stresses that create complex flow patterns not captured by the acoustic Doppler profiler in the floor of the breach (R. Rowland, pers. comm., 2019).

Subsurface flow through the rock-fill causeway is considered significant yet very difficult to quantify $[24,46,49]$. Subsidence of the causeway into soft lake sediments has necessitated continual additions and upgrades of causeway materials (e.g., [36]) changing the subsurface hydrologic characteristics of the causeway as well as reducing the effectiveness of the original culverts over time.

It has long been recognized that less dense south arm water has flowed from south-to-north and denser north arm water has flowed north-to-south through the culverts, breach, and in the subsurface through the causeway [13]. South-to-north flow is favored by differential elevation head between the two arms of the lake, north-to-south flow is favored by density differences between the two arms. The existence of a distinct layer of saline deep, north arm water in the southern arm (the deep brine layer or DBL) was first recognized in 1966 [42] (Fig. 2) and has been an irregular and poorly understood feature of the lake ever since. The significantly higher density of the DBL inhibits mixing with less saline, overlying south arm brines. The result is highly anoxic water with elevated concentrations of dissolved sulfides and metals $[8,30]$. In general, the DBL has been more pronounced and long-lasting north of the bathymetric sill that bisects the south arm of Great Salt Lake (Fig. 1).

Understanding the cycling of nutrients and mercury in Great Salt Lake has been a longstanding research focus $[8,18,30,33$, 43]. In 2007, human consumption advisories were issued for three species of ducks found in marshlands adjacent to Great Salt Lake due to high levels of mercury in the bird tissue [40]. Subsequent geochemical studies revealed very high concentrations of methylmercury in the deep brine layer $[17,30,32]$ suggesting the DBL may have been the source for the mercury observed in the water fowl $[1,44]$. However, exact sources and pathways

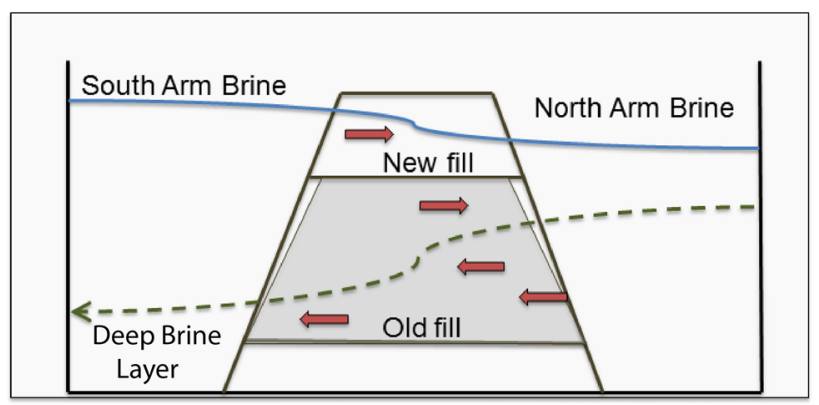

Fig. 2 Cartoon of Great Salt Lake rock-causeway cross section showing bidirectional flow leading formation of the Deep Brine Layer (DBL) ( adapted from [24], Fig. 3)

of mercury in Great Salt Lake ecosystem have yet to be definitively worked out $[32,51]$.

Given the possible importance of subsurface causeway flux to deep brine layer formation as well as the overall water balance of the lake, quantitative models have attempted to characterize the subsurface hydrologic regime of the causeway. A model based on the subsurface finite difference code of Pinder and Cooper [34] was originally developed by Wadell and Bloke [46]. Wold et al. [49] and Loving et al. [24] then used the more refined model of Sanford and Konikow [39] to simulate subsurface causeway flow. Calibration and validation of this subsurface model was done largely with dye studies. The two drivers of flux through the causeway were clearly identified: (1) a head gradient between the higher south arm driving south-to-north flow in the upper portion of the causeway and (2) north-to-south flow in the lower portion of the causeway, culverts, and breach driven by horizontal density gradients (Fig. 2). Validation of the USGS model was undertaken during the 1990s, a period of relatively high lake levels.

During the past decade, two studies using mass balance techniques have shed additional light on the behavior of Great Salt Lake. Mohammed and Tarboton [28] examined the sensitivity of lake elevations and volume to lake inputs between 1950 and 2010 as well as sensitivity to future climate change. White et al. [48] used a similar approach to examine scenarios for opening of the breach in 2016.

As a closed-basin lake, Great Salt Lake is very responsive to regional climate changes in the Great Basin. For much of the past decade, an extended drought has brought lake elevation to historic (north arm) and near historic (south arm) lows. Several features of the 2008-2015 period of low lake level present an opportunity to construct a mass model of Great Salt Lake that is simpler but more temporally detailed than those of Mohammed and Tarbonton [28] and White et al. [48]. The most important inflows to the lake have relatively complete records during this 
period. In particular, gauging of the causeway breach, Bear River Bay discharge, and Farmington Bay discharge during this period of time provide a rich data set some of which was unavailable to earlier Great Salt Lake researchers (Fig. 1) (Table 1). Furthermore, minor flows and ultimate collapse of the culverts during this time period allow their contribution to the water balance and their role in formation of the deep brine layer in the southern arm to be quantitatively assessed.

With these simplifications in place, key questions regarding Great Salt Lake can be addressed with this simple mass balance model. (1) What is the relative importance of density-driven vs. head-driven flow through the causeway (Fig. 2)? (2) What are the relative roles of the culverts, breach, and subsurface flow in maintaining the deep brine layer? 3) How does a mass balance model compare to published numerical models regarding subsurface causeway flux $[24,49]$ ?

\section{Methodology}

\subsection{Data sources}

Data for the mass balance model were largely derived from publically available resources. The temporally varying surface area of the lake was calculated from the bathymetric data set of Baskin $[5,6]$ in conjunction with USGS lake elevation data (Table 1). Surface area of Farmington and Bear River bays (Fig. 1) was not included in this study although they have been a part of previous mass balance studies $[28,48]$.
Since construction of the causeway, the U. S. Geological Survey (USGS) has been responsible for installing and maintaining water elevation gauges in the north arm (just north of the causeway) and south arm (at the marina at the south end of the lake) (Fig. 1). Additional sampling stations subsequently have been established throughout the lake (https://maps.waterdata.usgs.gov/mapper/).

Although stream discharge data for the period of this paper (2008-2015) are relatively complete there are some gaps. The USGS stream gauge at the Bear River Bay bridge (Fig. 1) was discontinued in 2013 and is missing for the first part of 2008. A polynomial fit between the Bear River Bay bridge and the gauge upstream at Corrine was developed with the 2009-2013 data and used to approximate flow at the Bear River Bay bridge for early 2008 and 2013-2015. Shorter gaps in the data were the result of equipment failure. Due to these gaps and the variable nature of the daily discharge data, monthly averages were calculated and reported all for discharge as well as elevation measurements.

A particularly important and useful, relatively recent (2003) gauging station is located at the causeway between Farmington Bay and the main body of Great Salt Lake (Fig. 1). Discharge measurements at this location integrate water input from a part of the Jordan River and numerous smaller streams discharging directly into Farmington Bay plus or minus Farmington Bay evaporation and precipitation thus simplifying previous mass balance models which had to account for these diverse, smaller, and highly variable water inputs. Weber River and Goggin Canal discharge data are considered accurate and relatively complete.

Table 1 Data sources for mass balance model

\begin{tabular}{|c|c|c|}
\hline Variable & Data availability (interval) & Source \\
\hline Weber River near Plain City $\left(\mathrm{K}_{\mathrm{r}}\right)$ & 1907 to present (daily) & USGS site $10,141,000$ \\
\hline Goggin Drain discharge $\left(\mathrm{K}_{\mathrm{r}}\right)$ & 1963 to present (daily) & USGS site $10,172,630$ \\
\hline Causeway breach discharge $\left(\mathrm{K}_{\mathrm{br}}\right)$ & 2008 to present (daily) & USGS site $10,010,020$ \\
\hline Bear River Bay discharge (data) $\left(\mathrm{K}_{\mathrm{r}}\right)$ & 2008 to 2013 (daily) & USGS site $10,010,060$ \\
\hline $\begin{array}{l}\text { Bear River Bay discharge (interpolation } \\
\text { from Corrine station) }\left(\mathrm{K}_{\mathrm{r}}\right)\end{array}$ & Early 2008 and 2013 to present (daily) & USGS site $10,126,000$ \\
\hline Farmington Bay discharge $\left(\mathrm{K}_{\mathrm{r}}\right)$ & 2003 to 2016 (daily) & USGS site $410,401,112,134,801$ \\
\hline East and west culvert discharge & 1997, 2011 to present (irregular) & USGS sites $411,325,112,400,701$ and $411,318,112,334,001$ \\
\hline South arm lake level $\left(\Delta \mathrm{V}_{\mathrm{S}}\right)$ & 1847 to present ( $15 \mathrm{~min})$ & USGS site $10,010,000$ \\
\hline North arm lake level $\left(\Delta \mathrm{V}_{\mathrm{N}}\right)$ & 1966 to present ( $15 \mathrm{~min})$ & USGS site $10,010,100$ \\
\hline Water density (USGS sites 2565 and 3510) & 2010 to present (irregular) & USGS sites $410,644,112,382,601$ and $405,356,112,205,601$ \\
\hline Water density (Utah Geological Survey) & 2008 to present (irregular) & UGS sites (FB2, AC3, AS2) \\
\hline Precipitation $\left(\mathrm{K}_{\mathrm{ps}}, \mathrm{K}_{\mathrm{pN}}\right)$ & 2008 to 2016 (daily) & $\begin{array}{l}\text { National Climate Data Center (https://www.ncdc.noaa. } \\
\text { gov/cdo-web/) }\end{array}$ \\
\hline Great Salt Lake hypsometry & & Baskin $[5,6]$ \\
\hline
\end{tabular}

Parentheses represent variable in the mass balance model

SN Applied Sciences 
Discharge measurements through the two causeway culverts, both north-to-south and south-to-north, were made at irregular intervals by the USGS. These data are not reported on the public web site (https://maps.waterdata. usgs.gov/mapper/) but were made available as a spreadsheet to the author.

Since World War II, the Utah Geological Survey (UGS) has collected water quality data that includes density measurements at a variety of stations within the lake (Table 2). Additional density data have been collected by the USGS at Great Salt Lake marina and in the north arm as well as at various stations in the southern arm over the past couple of decades (Fig. 1). The only water quality data reported at these two stations are density. The UGS measurements were made at irregular intervals (typically 4-8 times per year) but the record contains gaps as long as multiple years. UGS density measurements were typically made for the entire water column at $1.5 \mathrm{~m}$ intervals and rarely $0.3 \mathrm{~m}$ intervals. USGS measurements are usually only for the top and bottom of the water column (Fig. 3). Both UGS and USGS bottom density measurements were made $\sim 0.5 \mathrm{~m}$ above the bottom to avoid interaction with the bottom sediments. Density data are reported in this paper as quarterly averages from both UGS and USGS stations. Where only salinity and temperature data are reported, density was calculated using the equation of state of Naftz et al. [31].

Daily precipitation values were downloaded from publically available data of the National Climate Data Center (NCDC) (https://www.ncdc.noaa.gov/cdo-web/) at 10 stations surrounding the lake (Fig. 4). This approach differs from Mohummad and Tarboton (2012) who used the interpolation-based output from the Parameter-elevations on Independent Slopes Model (PRISM) [10]. The NCDC data were spatially interpolated with Matlab routines by inverse distance weighting and used as input for the mass balance model. For stations in which some daily data were missing, the weighing factors were recalculated as appropriate.

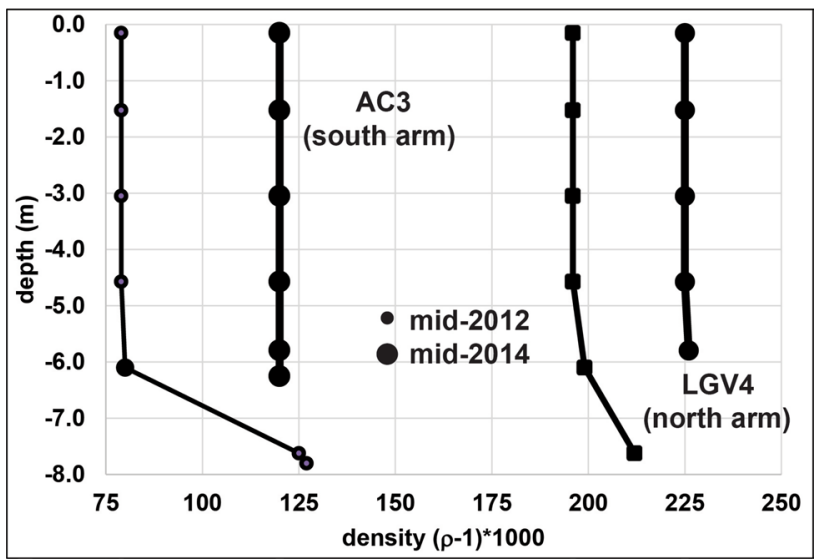

Fig. 3 Typical density profiles for Utah Geological Survey locations AC3 (south arm) and LGV4 (north arm) for a period of widespread dense brine layer (DBL) (mid-2012) and lack of the DBL (mid-2014)

\subsection{Mass balances}

A simple mass balance model of the entire Great Salt Lake consists of river inputs, precipitation, groundwater inflows, and precipitation minus evaporation;

$\Delta \mathrm{V}_{\mathrm{T}}=\mathrm{K}_{\mathrm{r}}+\mathrm{K}_{\mathrm{pT}}-\mathrm{K}_{\mathrm{eT}}+\mathrm{K}_{\mathrm{gw}}$

All units are expressed as $\mathrm{m}^{3} / \mathrm{s} . \Delta \mathrm{V}_{\mathrm{T}}$ represents total net volume change in the lake as determined from gauge height changes of the lake and lake hypsometry $[5,6], K_{r}$ is total river input; $\mathrm{K}_{\mathrm{pT}}$ is total precipitation of the combined south and north arms, $\mathrm{K}_{\mathrm{eT}}$ is total evaporation; and $\mathrm{K}_{\mathrm{gw}}$ is groundwater input (Fig. 5) (Table 1). A time step of one day was used for all variables. Monthly averages were then calculated for presentation of model results. The volume flux of both precipitation and evaporation was adjusted for changing lake level with time.

The amount of groundwater inflow to the lake is not precisely known and has been quantified over spatially limited areas (e.g., [3]). Previous studies at higher lake

Table 2 Summary of Great Salt Lake sampling stations for density

\begin{tabular}{lllllll}
\hline Station & Easting & Northing & $\begin{array}{l}\text { Bottom } \\
\text { elevation }(\mathrm{m})\end{array}$ & Sampling interval & Period of record & $\begin{array}{l}\text { Periods of top-bottom strati- } \\
\text { fication 2008 -2015 }(>5 \mathrm{~kg} / \\
\left.\mathrm{m}^{3}\right)\end{array}$ \\
\hline AS2 (UGS) & 394,123 & $4,521,193$ & 1271.6 & Full column, $1.5 \mathrm{~m}$ interval & $4 / 1969$ to present & $7 / 2008$ to $5 / 2014$ (irregular) \\
AC3 (UGS) & 378,337 & $4,539,758$ & 1272.0 & Full column, $1.5 \mathrm{~m}$ interval & $6 / 1966$ to present & $7 / 2009$ to $10 / 2013$ \\
FB2 (UGS) & 377,394 & $4,554,765$ & 1272.0 & Full column, $1.5 \mathrm{~m}$ interval & $6 / 1966$ to present & $7 / 2008$ to $5 / 2014$ (irregular) \\
RT4 (UGS) & 355,600 & $4,558,105$ & 1273.8 & Full column, $1.5 \mathrm{~m}$ interval & $7 / 1984$ to present & None \\
2565 (USGS) & 362,258 & $4,552,512$ & 1272.0 & Top, bottom & $8 / 1985$ to present & $6 / 2010^{*}$ to $7 / 2014$ \\
3510 (USGS) & 386,382 & $4,528,409$ & 1272.0 & Top, bottom & $8 / 1985$ to present & $6 / 2011$ to 4/2014 \\
\hline
\end{tabular}

*Beginning of record for 2008-2015 
Fig. 4 a Location of meteorological stations used to calculate monthly precipitation. RO, Rossette; TA, Thatcher; GA, Garland; BC, Brigham City waste treatment plant; WW, West Weber; WH, West Haven; OG, Odgen Hinkley Airport; SL, Salt Lake International Airport; UT, Utah Test Range; MG, Magna; GV,Grantsville; AR, Aragonite. Stations WW, WH, and DG were averaged into a single value. Squares represent stations used to calculate both north and south arm precipitation; circles represent stations only used to calculate north arm precipitation; triangles represent station only used to calculate south arm precipitation. b Summary of precipitation near the Great Salt Lake, 2009-2015. Triangles represent south arm precipitation, $x$ 's represent north arm precipitation $\mathbf{a}$
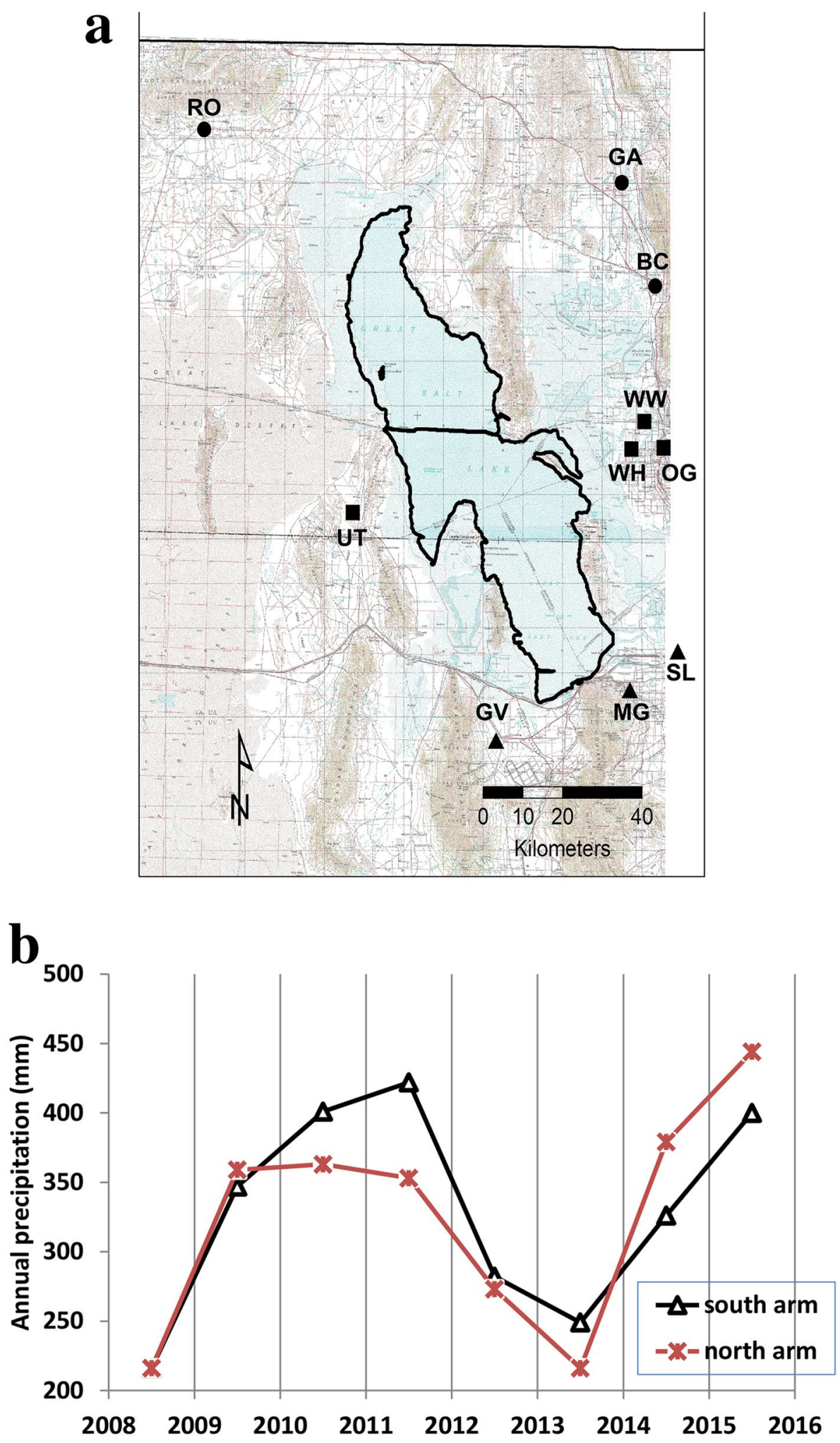

levels suggest the groundwater component is minor (approximately $3 \%$ of total lake input) $[28,45]$. That value is adopted in this study although it must be considered a potential source of error in the model results.
Total lake volume change $\left(\Delta \mathrm{V}_{T}\right)$, total river input $\left(\mathrm{K}_{\mathrm{R}}\right)$, and total precipitation $\left(\mathrm{K}_{\mathrm{pT}}\right)$ can be derived from existing data bases (Table 1 ) leaving total lake evaporation as the only unknown in Eq. (1). 


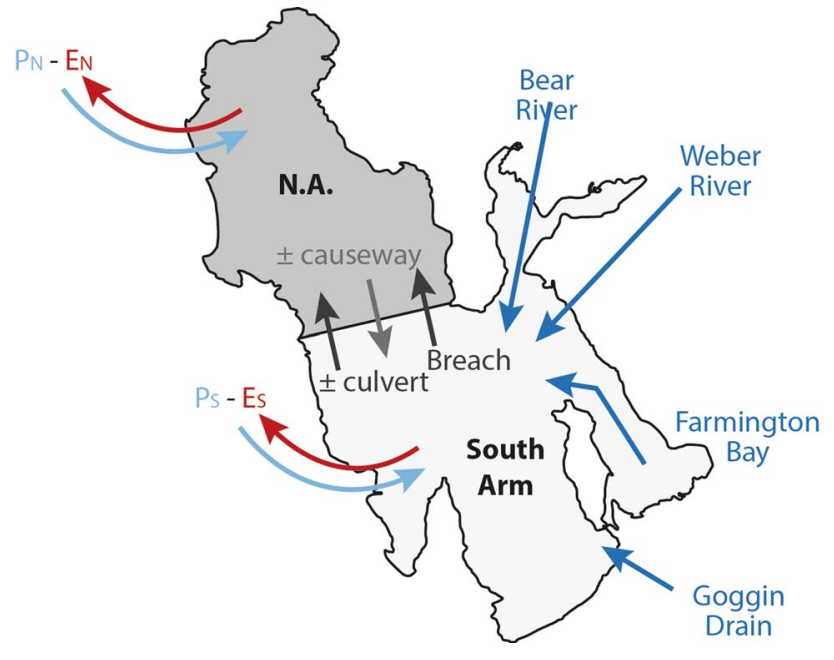

Fig. 5 Diagrammatic representation of Great Salt Lake mass balance model (W. Wurtsburgh, pers. comm.)

South arm mass balances consist of river inflows, precipitation minus evaporation, and net flux through the causeway breach, culverts, and subsurface flow through the rock-fill causeway. With no river inflows, the mass balance for the northern arm is simpler (Fig. 5). The water mass balance equations are as follows:

$\Delta \mathrm{V}_{\mathrm{S}}=\mathrm{K}_{\mathrm{r}}+\mathrm{K}_{\mathrm{cu}, \mathrm{N}}-\mathrm{K}_{\mathrm{cu}, \mathrm{S}}+\mathrm{K}_{\mathrm{pS}}-(1-\mathrm{z}) \mathrm{K}_{\mathrm{eT}}-\mathrm{K}_{\mathrm{br}}-\mathrm{K}_{\mathrm{ca}}+\mathrm{K}_{\mathrm{gw}}$

$\Delta \mathrm{V}_{\mathrm{N}}=\mathrm{K}_{\mathrm{br}}+\mathrm{K}_{\mathrm{ca}}+\mathrm{K}_{\mathrm{pN}}+\mathrm{K}_{\mathrm{cu}, \mathrm{S}}-\mathrm{K}_{\mathrm{cu}, \mathrm{N}}-\mathrm{ZK}_{\mathrm{eT}}+\mathrm{K}_{\mathrm{gw}}$

$\Delta \mathrm{V}_{\mathrm{S}}$ and $\Delta \mathrm{V}_{\mathrm{N}}$ represent net volume change in the south and north arms of the lake as determined from gauge height changes of the lake and lake hypsometry; $\mathrm{K}_{\mathrm{r}}$ is river inputs; $\mathrm{K}_{\mathrm{br}}$ is causeway breach flux; $\mathrm{K}_{\mathrm{cu,N}}$ is north-to-south culvert flux; $\mathrm{K}_{\mathrm{cu}, \mathrm{S}}$ is south-to-north culvert flux; $\mathrm{K}_{\mathrm{ps}}$ and $\mathrm{K}_{\mathrm{pN}}$ is precipitation to the south and north arms, respectively; $\mathrm{K}_{\mathrm{ca}}$ is net subsurface flux through the causeway; $\mathrm{K}_{\mathrm{gw}}$ is groundwater flow; $\mathrm{K}_{\mathrm{eT}}$ is total evaporation as calculated in Eq. (1); and $\mathrm{z}$ is the fraction of evaporation in the north arm divided by total lake evaporation (Table 1).

The net result is two equations and two unknowns $\left(\mathrm{K}_{\mathrm{ca}}\right.$ and $z)$. Unfortunately, the two equations are not independent since the two unknowns have opposite signs in each equation. Furthermore, while most components of Eqs. (2) and (3) have solid, publicly reported time series data (Table 1), culvert flux data $\left(\mathrm{K}_{\mathrm{cu}, \mathrm{N}}\right.$ and $\left.\mathrm{K}_{\mathrm{cu}, \mathrm{S}}\right)$ were collected over irregular time periods. Sensitivity analyses of these three components $\left(\mathrm{z}, \mathrm{K}_{\mathrm{cu}, \mathrm{N}}\right.$ and $\left.\mathrm{K}_{\mathrm{cu}, \mathrm{S}}\right)$ are discussed below.

\section{Results}

\subsection{Total lake mass balances}

Lake volume increases in the spring before declining significantly in the late summer with seasonal changes as much as 30\% (Fig. 6a). Both lake volume and river flux were anomalously high in 2011 (Fig. 6a, b) reflecting very high precipitation that year (Fig. 6c). Precipitation was also high in the spring of 2015 although lack of associated higher river flow and lake volume may reflect upstream reservoir storage after a period of prolonged regional drought.

Calculated evaporation (Fig. 6d) follows a pattern similar to that of total lake volume with maximum water loss in the hottest part of summer. Mass balance calculations of yearly evaporation rates $(\mathrm{m} / \mathrm{yr})$ are reasonably close to those reported by Mohammed and Tarboton [28] (Table 3). The mass balance calculations produce small negative evaporation in the winter months of 2008-2012 suggesting small errors in the inputs to Eq. (1).

Mohammed and Tarboton [28] calculated evaporation by two methods: (1) a modified Penman method incorporating a number of atmospheric variables (the "climate" method) and (2) a mass balance approach similar to the one in this study. Their climate method produced evaporation rates $5-15 \%$ higher than the mass balance method. Mohammed and Tarboton [28] suggest that some inputs to the mass balance model may be missing or poorly defined (e.g., groundwater inputs). Similar issues may account for the negative evaporation rates calculated for small time intervals calculated in this study (Fig. 6d).

\subsection{Mass balances of the north and south arms}

The seasonal nature of lake elevation in both the north and south arms of the lake has long been recognized (e.g., Arnow and Stephens [4]). Maximum elevation for both arms is typically reached in May soon after peak spring runoff (Fig. 7a, b). South-to-north elevation gradients which are believed to be a primary driver of south-tonorth flux through the causeway likewise show seasonal peaks although the signal of the elevation difference is smaller than the seasonal north and south arm elevation changes (Fig. 7). Closure of the culverts in 2014 resulted in significantly higher elevation differences in the two lake arms (Fig. 7c).

\subsection{Sensitivity analyses}

One of the key goals of the mass balance model is insight into the magnitude of subsurface flux through the 
A

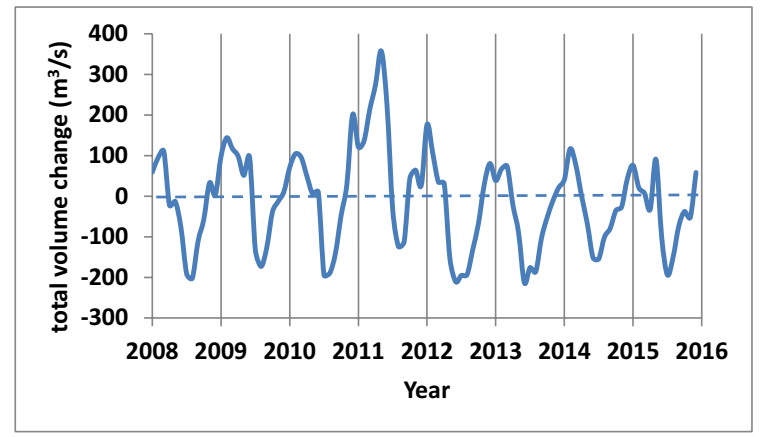

C

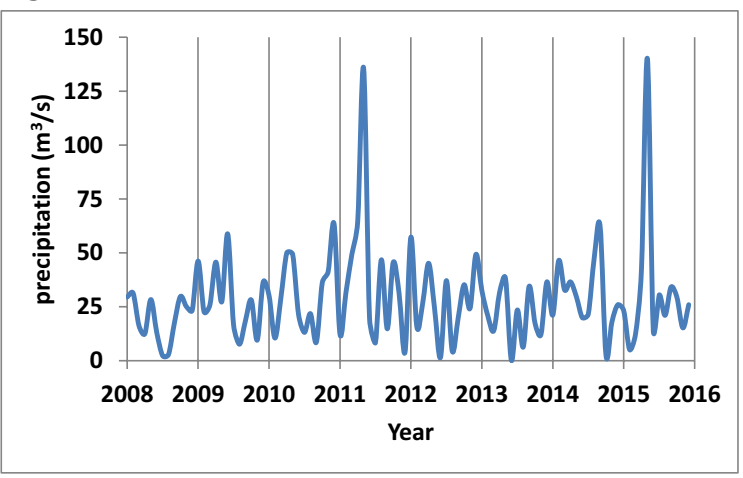

B

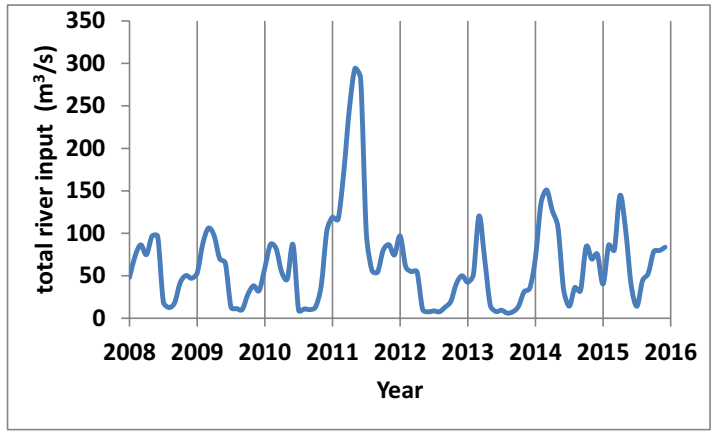

D

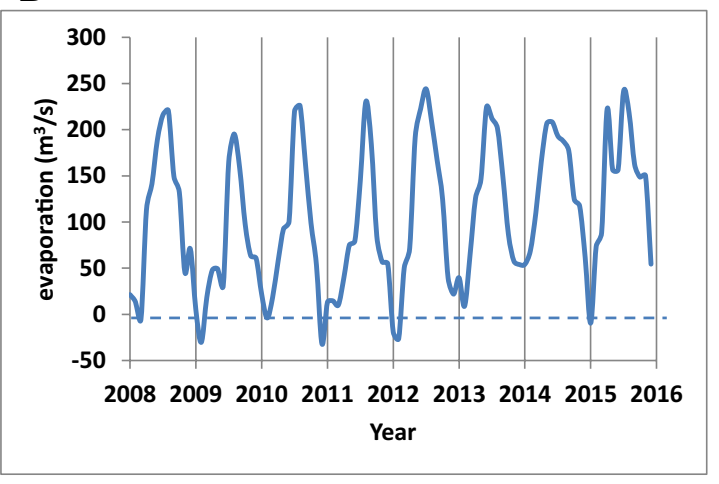

Fig. 6 Results of whole Great Salt Lake mass balance model. a Total volume change calculated using USGS lake elevation (Table 1) and hyposometric data $[4,5]$. b Total river input. c Precipitation. d Computed evaporation

Table 3 Yearly summary of mass balance model calculations $\left(\mathrm{km}^{3}\right.$ unless otherwise specified)

\begin{tabular}{lllllllll}
\hline & 2008 & 2009 & 2010 & 2011 & 2012 & 2013 & 2014 & 2015 \\
\hline River input & 1.74 & 1.60 & 1.57 & 4.42 & 1.11 & 1.08 & 2.45 & 2.21 \\
Total lake evaporation & 3.38 & 2.19 & 2.59 & 2.51 & 3.34 & 3.52 & 4.33 & 4.41 \\
Total lake evaporation (m/yr) & 1.19 & 0.77 & 0.92 & 0.78 & 1.04 & 1.18 & 1.54 & 1.60 \\
Total lake precipitation & 0.62 & 0.61 & 0.99 & 1.22 & 0.90 & 0.70 & 0.95 & 1.16 \\
South-to-north breach flux & 0.63 & 0.51 & 0.34 & 2.09 & 1.51 & 0.52 & 0.30 & 0.07 \\
North-to-south breach flux & n.a & .0021 & .0002 & .0044 & .0035 & .0127 & .0065 & .0028 \\
North-to-south culvert flux (poly.) & 0.17 & 0.23 & 0.41 & 0.54 & 0.14 & 0.25 & - & - \\
South-to-north culvert flux (poly.) & 0.25 & 0.50 & 0.73 & 0.58 & 0.39 & 0.01 & - & - \\
South-to-north culvert flux (spline) & 0.27 & 0.68 & 0.48 & 0.35 & 0.07 & 0.06 & - & - \\
Net south-to-north causeway flux & -0.06 & -0.27 & 0.21 & -0.03 & -0.92 & -0.05 & 0.54 & 0.64 \\
\hline
\end{tabular}

causeway ( $K_{c a}$ in Eqs. 1 and 2). However, since flow through the culverts $\left(\mathrm{K}_{\mathrm{cu}, \mathrm{N}}, \mathrm{K}_{\mathrm{cu}, \mathrm{S}}\right)$ and the relative proportion of evaporation in the north and south arms (z) in Eqs. 2 and 3, are difficult to precisely quantify, their relative importance must be evaluated with sensitivity analyses.

\subsubsection{Culvert flows}

Because flow measurements of the east and west culverts were made at irregular intervals, monthly culvert discharge was estimated by two different approaches. Culvert flow of dense north arm water to the south took place in the deeper portions of the culvert and thus probably did not have a significant seasonal signal. Third-order polynomial fits of these data show relatively good correlation (Fig. 8a, b). Flow of less dense south arm water to the north, however, may have been influenced by relatively high south-to-north elevation gradients and therefore had a seasonal signal (Fig. 8c, d). These data were interpolated with two methods: 1) cubic splines and 2) fitting with a 
A

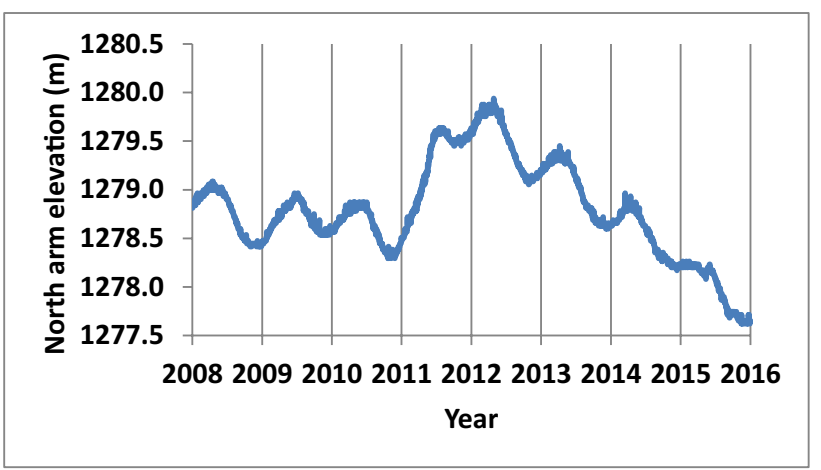

B

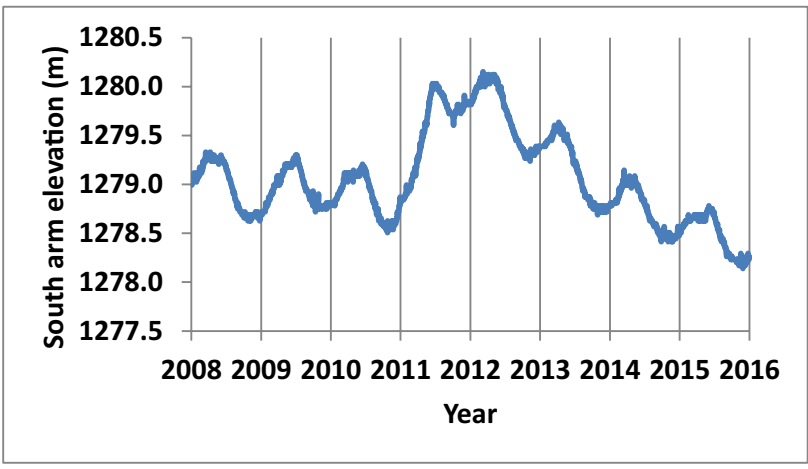

C

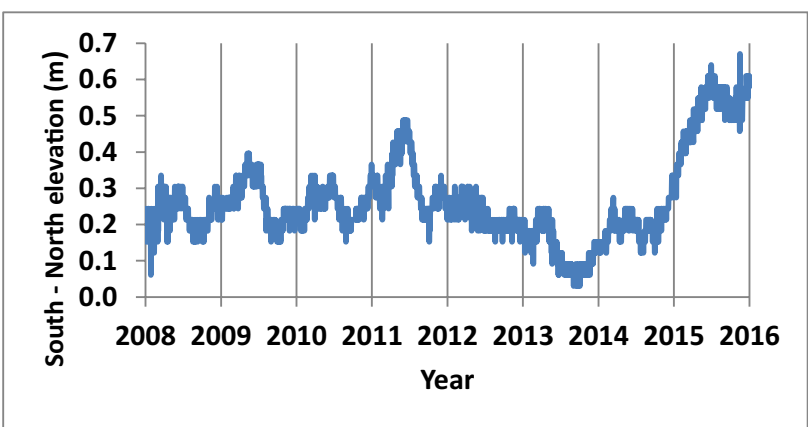

Fig. 7 Great Salt Lake hydrograph (2009-2015). a South arm elevation $(m)$. b North arm elevation (m). c (South-north) elevation difference

third-order polynomial. Correlation of the polynomial was poor $\left(R^{2}=0.3624\right.$ and 0.3664$)$. Final collapse and closure of the west culvert occurred in late 2012 and the east culvert closed in late 2013 and for subsequent years, culvert flow does not enter into the mass balances (Eq. 2 and 3). Note that calculated south-to-north flow after 2012 in the east culvert is very close to zero in both methods (Fig. 8c).

\subsubsection{Relative evaporation rates}

Since salinity of the north arm of Great Salt Lake is $40-100 \%$ higher than that of the south arm, north arm evaporation would presumably be lower than south arm evaporation [28], their Fig. 10). A baseline simulation of net subsurface flux $\left(\mathrm{K}_{\mathrm{ca}}\right)$ in this study was calculated using spline calculations for south-to-north culvert flux and evaporation assuming differential salinity of the north and south arms has no effect on evaporation rates (Fig. 9a). Mass balance model calculations with evaporative flux in the north arm $20 \%$ lower than that of the south arm produce only minor changes in calculated subsurface causeway flux (Fig. 9b). Likewise, the method for calculating the flow through culverts (spline or polynomial interpolation does not significantly change either the magnitude or patterns of net subsurface causeway flux (Fig. 9c).

\subsection{Controls of deep brine layer formation}

For this study, the existence of the deep brine layer (DBL) is defined as a significant density contrast $\left(>5 \mathrm{~kg} / \mathrm{m}^{3}\right)$ between the bottom sampling point and the sampling point immediately above (typically $2.3 \mathrm{~m}$ in the UGS data). Density contrasts in the water column above the bottom two sampling points are typically $<5 \mathrm{~kg} / \mathrm{m}^{3}$ and can be attributed at least partially to spring runoff, seasonal temperature contrasts, or analysis error. Because USGS data are only reported at the surface and bottom, the UGS data are reported in a similar fashion.

Starting around 1970, stratification was a continuous feature for nearly 25 years as a result of significant north-to-south flow through the breach, culverts, and porous causeway. Shorter DBL events are documented in 1997-2004, 2006-2009, and 2011-2014 (Fig. 10). In addition to the three possible sources of deep brine water, water depth may play a role in maintaining the deep brine layer over extended periods of time. None of these factors are exclusive to each other and all will be examined here.

\subsubsection{Pre-2008}

The prolonged DBL period from 1970 to 1990 can be attributed to effective flow through the culverts, the relatively new, relatively porous rock causeway, and the high level and relatively deep water in the lake during that time period. The flooding and historically high lake levels of the early 1980s necessitated constructing the 47-m wide breach on the eastern side of the causeway at an elevation of $1280 \mathrm{~m}$ [13]. Two-way flow through this breach and a much deeper lake (which mitigates wind-induced mixing) no doubt enhanced post-1984 stratification (Fig. 10).

Disappearance of the DBL at the stations reported in 1993 can be attributed to clogging of the culverts, progressive compaction of causeway materials, and shallower lake levels [13]. In 2000, the causeway breach was deepened from 1280 to $1278 \mathrm{~m}$ [14] thus allowing two-way 
A

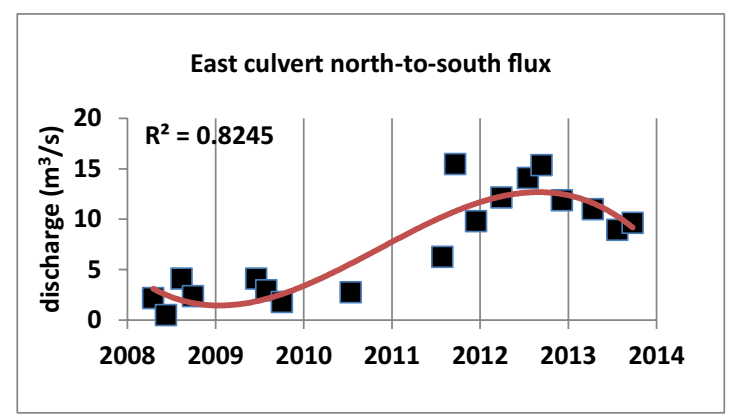

C

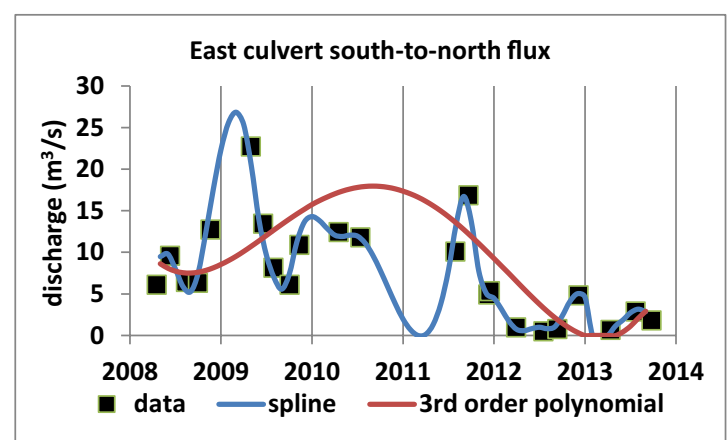

Fig. 8 Summary of east and west culvert measurements and approximations. a East culvert north-to-south flux. b West culvert north-to-south flux. c East culvert south-to-north flux. Blue line is a cubit spline fit of the data; red line is a 3rd order polynomial

exchange of water between the two lake arms to resume with subsequent strengthening of the DBL (Fig. 10).

\subsubsection{8-2015: breach and culvert flows}

The DBL is strongest close to the causeway where it has been identified $1.8 \mathrm{~km}$ south of the causeway in August, 2010 [18]. The DBL reappeared north of the south arm sill at USGS station 2565 at an unknown date before 2010 and then expanded throughout the south arm by 2011 (Figs. 1, 12). A distinct DBL had disappeared by early to mid-2014 through most of the south arm although it persisted close to the causeway at least until May, 2015 [25].

As declining lake elevation in the southern arm approached the1278 m mark, flow through the breach was minimal from 2008 to 2011 and 2013-2015 as well as being completely south-to-north (Fig. 12a, Table 3). As a result, the breach is not considered a viable candidate for source of DBL water for the 2011-2014 time frame. Total north-to-south flux through culverts $\left(\sim 15 \mathrm{~m}^{3} / \mathrm{s}\right.$ increasing to $\sim 30 \mathrm{~m}^{3} / \mathrm{s}$ ) (Fig. 8) suggest modest contribution to the DBL at the onset of stratification (Fig. 12b). As stratification in the south arm increased and achieved its maximum in 2013, culvert flow decreased and then ended.
B

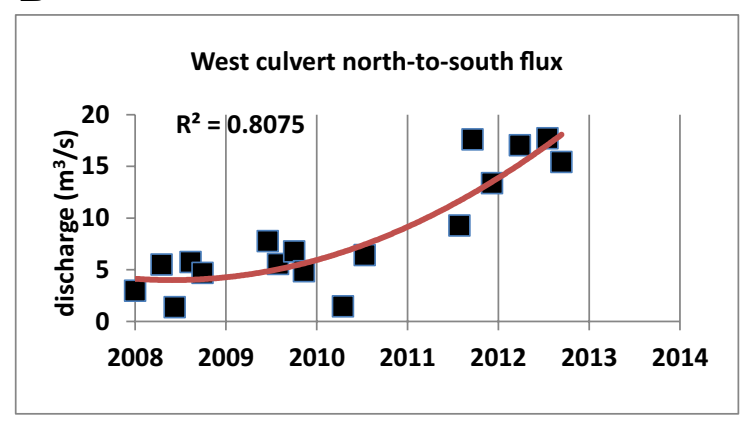

D

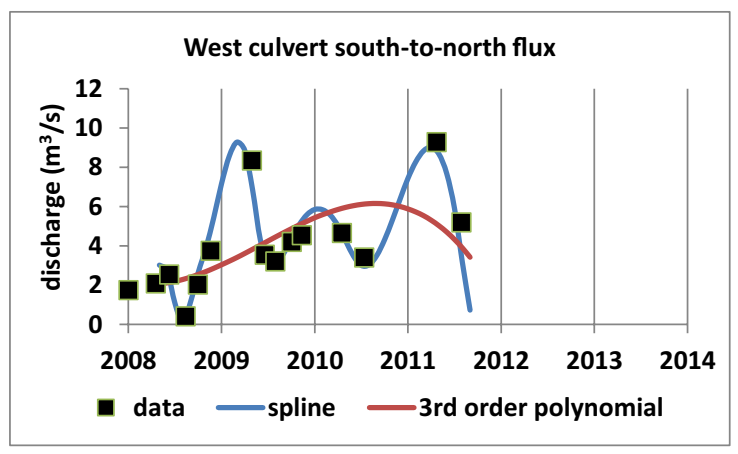

fit $\left(R^{2}=0.3624\right)$. d West culvert south-to-north flux. Blue line is a cubit spline fit of the data; red line is a 3rd order polynomial fit $\left(R^{2}=0.3664\right)$

\subsubsection{8-2015: water depth}

The persistence of the deep brine layer (DBL) depends critically on the degree of wind-induced mixing in the lower part of the water column. Obviously, transmission of wave energy to the sediment-water interface is favored by relatively low lake levels. The longest and strongest DBL episode occurred during a period of high lake level ( $1283 \mathrm{~m}$ during the 1980s and early 1990s) (Fig. 10). During the period of this study lake level was as low as $1278.5 \mathrm{~m}$ (Fig. 7).

The amount of bottom water mixing as function of lake depth can be examined with simple linear wave relationships. The dispersion equation relates radian wave frequency $(\omega)$, radian wave number $(k)$, gravity $(g)$ and water depth (H) (e.g., [35]:

$\omega^{2}=g k \tanh (k H)$

While general wave parameters for Great Salt Lake have not been published, constraints can be derived from studies of other large lakes. For instance, peak wave periods are 4-12 s in Lake Ontario [26], 3-4 s [37] in Lake Tahoe, and 1.5-2.5 s in Lake Constance of Switzerland [41]. The

\section{SN Applied Sciences}


A

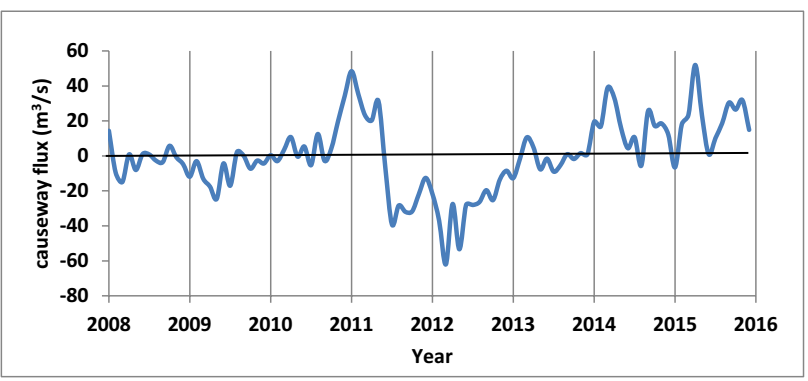

B

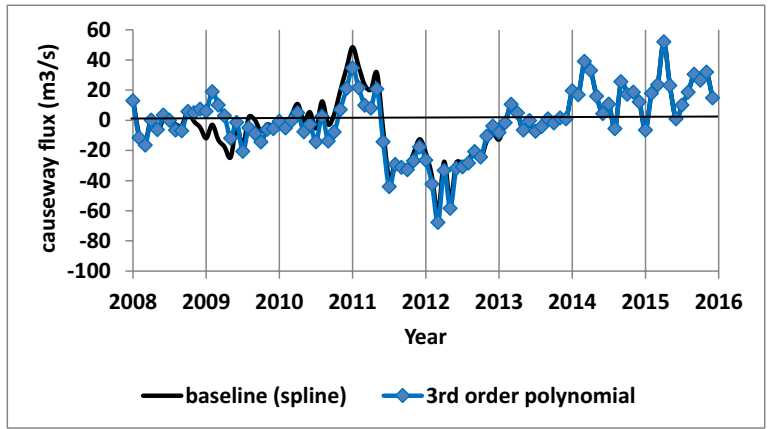

C

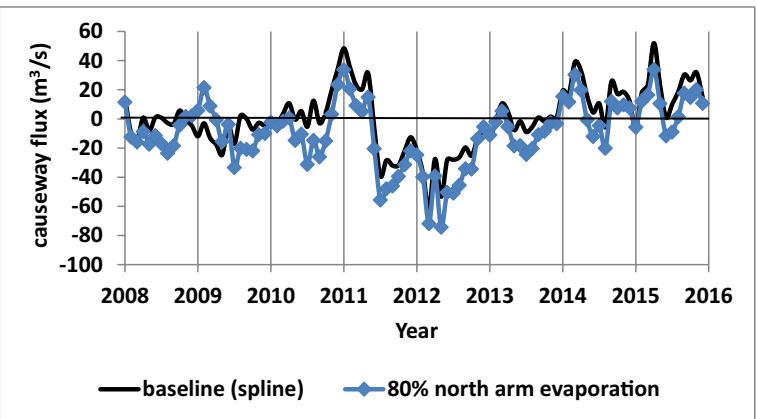

Fig. 9 Calculated net causeway flux. a Baseline calculation of subsurface causeway flux (spline interpolation of culvert flux, evaporation of north and south arms proportional to lake area). $\mathbf{b}$ Baseline calculation and north arm evaporation depressed by $20 \%$. C. Baseline calculation and polynomial interpolation of culvert flux

development of surface wind waves is related to maximum lake fetch which for Great Salt Lake is between that of Lake Ontario (maximum fetch $250 \mathrm{~km}$ ) and Lake Tahoe (maximum fetch $25 \mathrm{~km}$ ). Maximum Great Salt Lake wave period would thus be $\sim 7-8 \mathrm{~s}$. Applying Eq. (4) yields a radian wave frequency $(\omega)$ of 3-4 $\mathrm{s}^{-1}$ and a radian wave length $(k)$ of $0.3-0.4 \mathrm{~m}^{-1}$.

The absolute bottom velocity (Vo) which would be the primary factor in mixing the deep brine layer and can be expressed as [16]:

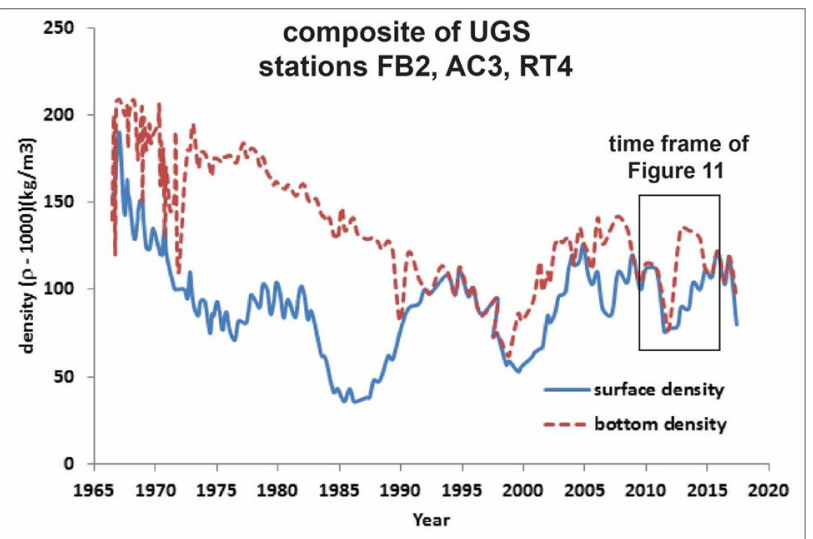

Fig. 10 Average vertical density $\left(\rho-1000, \mathrm{~kg} / \mathrm{m}^{3}\right)$ differences in south arm of the Great Salt Lake at Utah Geological Survey stations with the most continuous density records (FB2, AC3, AS2) (Fig. 1)

$V_{0}=A \frac{2 \pi \omega}{\sinh (\mathrm{kH})}$

A is wave amplitude or one half of significant wave height (SWH). Reported SWHs are $3 \mathrm{~m}$ for Lake Ontario, $\sim 0.8 \mathrm{~m}$ for Lake Tahoe and $\sim 0.5 \mathrm{~m}$ for Lake Constance. Equation (5) produces Vo for maximum Great Salt Lake typical depths during the 2011-2014 DBL episode (8.5-9.5 m) and the 1970-1990 DBL episode (10.5-11.5 m) (Fig. 13). Absolute maximum bottom velocity varies by approximately $50 \%(0.6-0.9 \mathrm{~m} / \mathrm{s})$ over the depth range for 2011-2014. This is considerably higher than typical bottom velocity $(\sim 0.3 \mathrm{~m} / \mathrm{s})$ of the historically high lake levels and extensive1970-1990 DBL period. While these calculations must be regarded as approximate, they suggest that lake depth was important in maintaining the DBL at high lake levels relative to lower lake levels of 2011-2014. A $1 \mathrm{~m}$ change in lake level (Figs. 7, 13) during 2011-2014 produces relatively high and consistent bottom water mixing.

\subsubsection{8-2015: causeway flow}

Unlike open water exchange via the culverts and breach, pressure on the causeway face is the driving force for water flux through the rock-fill causeway. South-to-north flow is the result of head gradient driven pressure expressed as:

$p=\rho g \Delta h$

$\rho$ is density, $g$ is gravity, and $\Delta h$ is the south-to-north head gradient.

North-to-south flow is driven by the pressure of northto-south density differences in the overlying water column: 

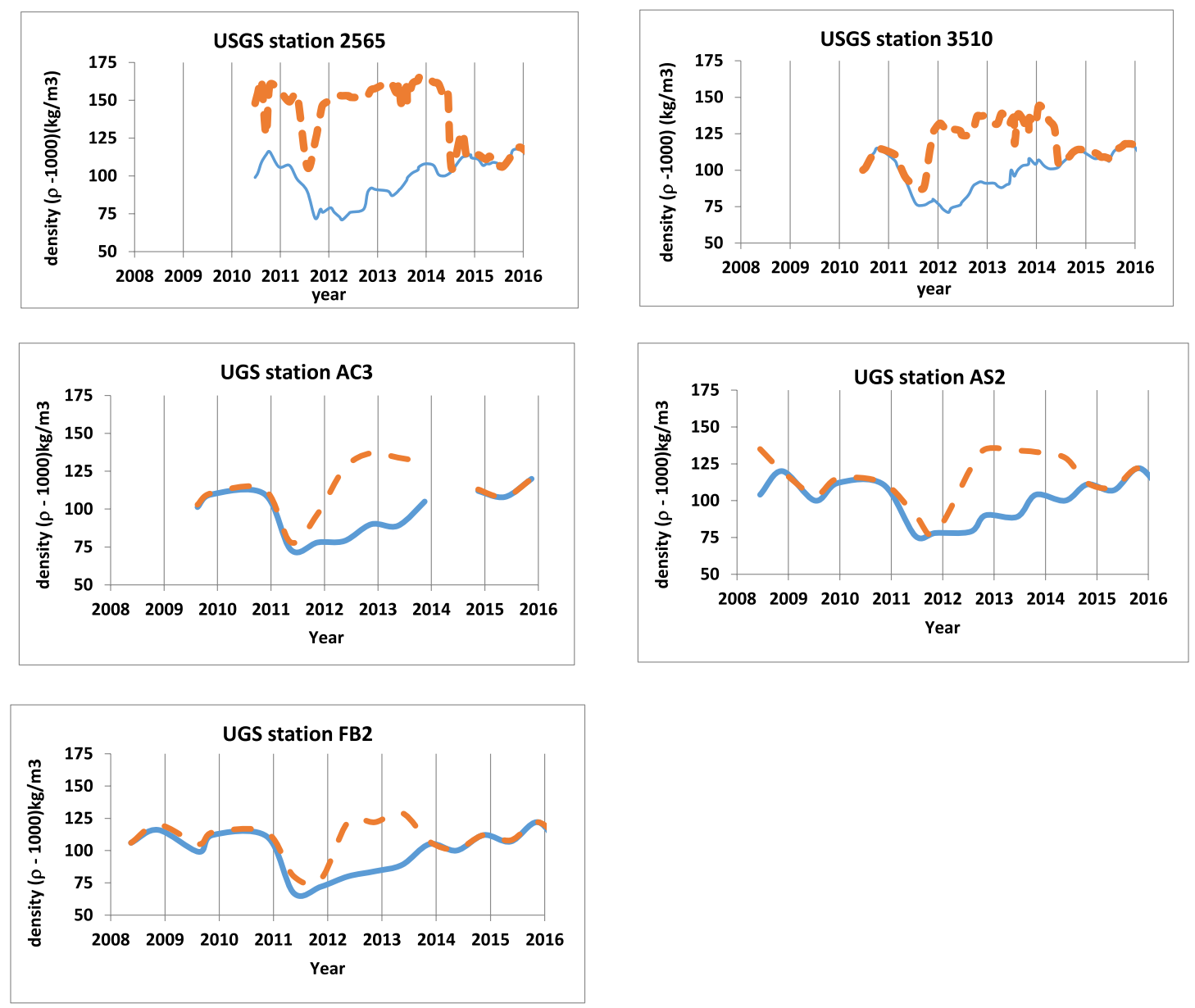

Fig. 11 Surface density (solid line) and bottom density (dashed line) for UGS station AS2, UGS station AC3, UGS station FB2, USGS station 2565, USGS sation 3510 (station locations shown in Fig. 1)

A

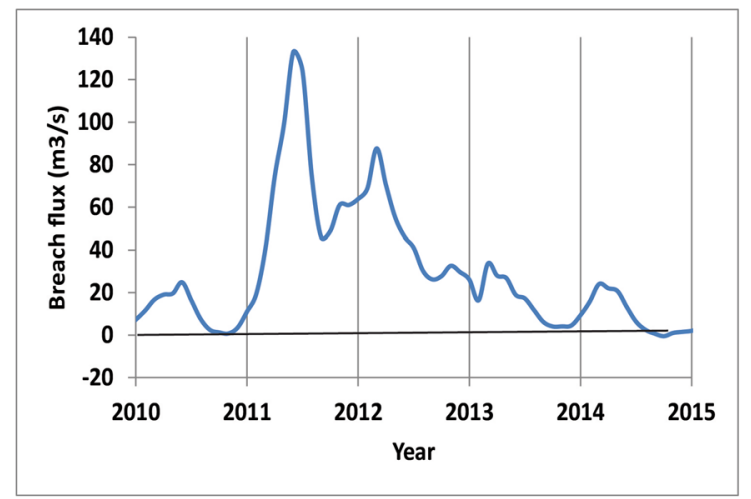

B

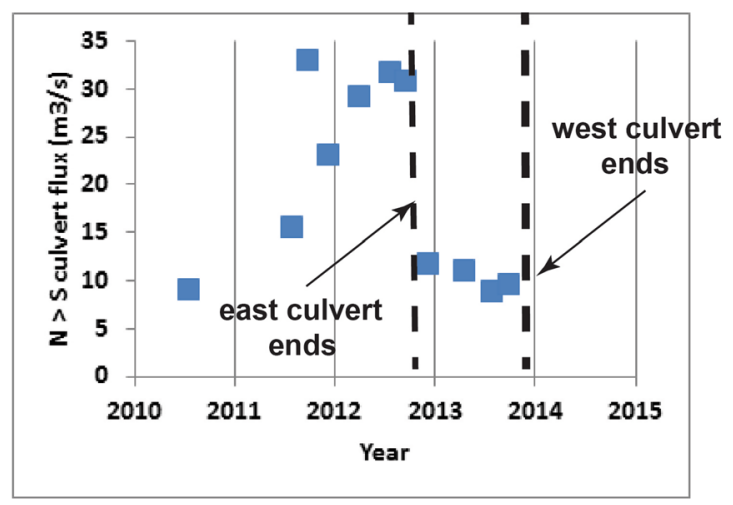

Fig. 12 a Breach flow for 2010-2015. b Combined flow of east and west culverts (Fig. 8). Medium-dashed line represents end of the west culvert; heavy dashed line represents end of the east culvert

$\Delta p=g\left(\rho_{N} H_{N}-\rho_{s} H_{s}\right)$
, where $\mathrm{H}_{\mathrm{N}}, \rho_{\mathrm{N}}$ and $\mathrm{H}_{\mathrm{S}}, \rho_{\mathrm{S}}$ are water depths and density in the north and south arms, respectively. Obviously, the pressure difference of Eq. (7) is maximum at the base of the 


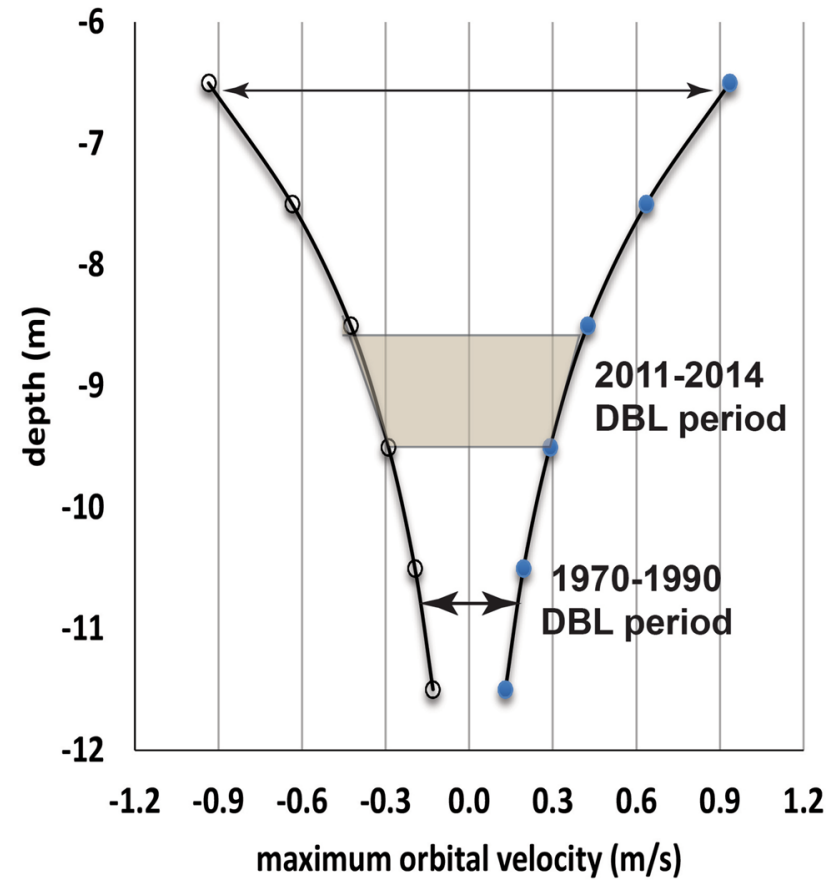

Fig. 13 Absolute orbital velocity for typical surface waves of Great Salt Lake as a function of depth

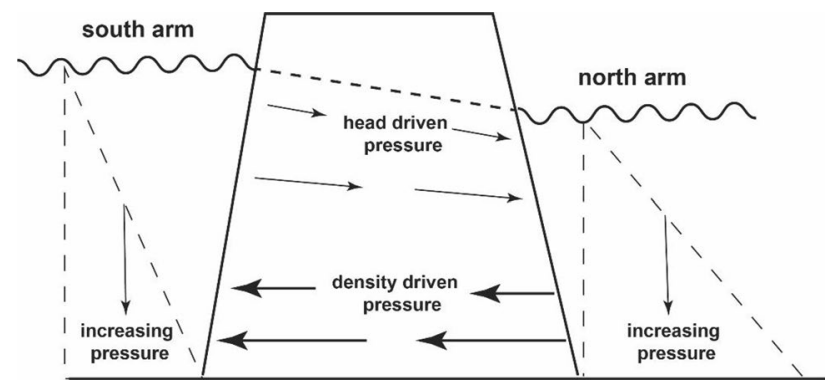

Fig. 14 Diagrammatic representation of two-way flow through the rock-fill causeway and resulting pressure prisms

causeway and the dominance of Eq. 6 or Eq. 7 at any given depth is unknown (Fig. 14). Furthermore, the force moving water through the causeway is the pressure of Eqs. 6 and 7 applied over the causeway surface area exposed to the water.

Calculation of both types of pressure shows a sharp increase in bottom pressure difference in the summer of 2011 (Fig. 15a), precisely the time of the widespread appearance of the deep brine layer (Fig. 11) and the maximum computed north-to-south causeway flux (Fig. 15b) as well as increased density difference between the north and south arms (Fig. 15c). It should be re-emphasized that the mass balance model only computes net subsurface flow through the causeway (Eqs. 2, 3). For much of the 2008-2015 period, the two-way subsurface flows were in
A

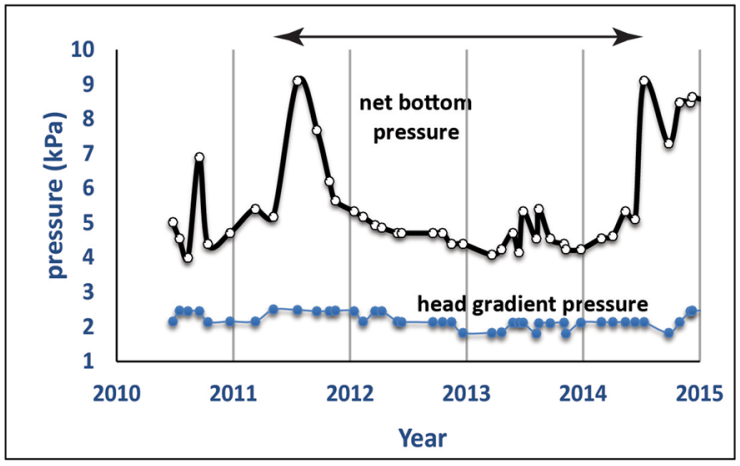

B
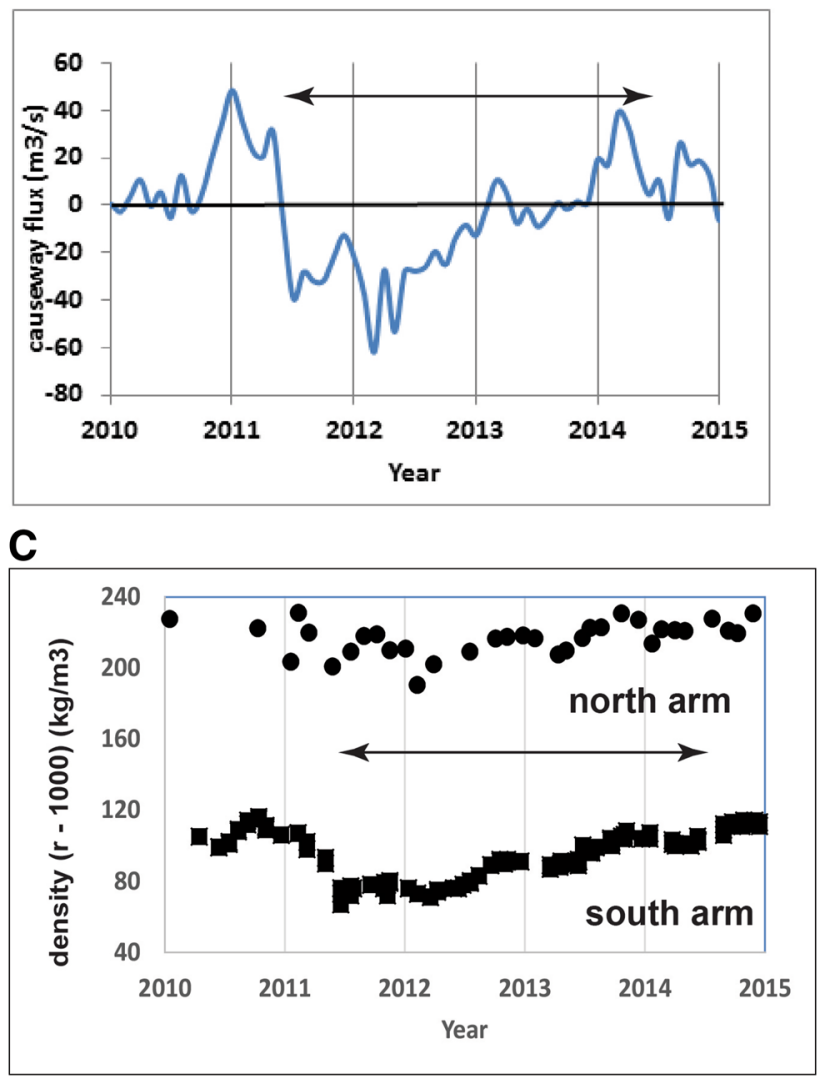

Fig. 15 a Net north-minus-south bottom pressure and head pressure gradient calculated from bottom density at UGS station VG4 and USGS station 2565 (Fig. 1) b Net causeway flux for 2010-2015. c Surface density calculated from the averages of south arm stations AC3, AS2, FB2, 2565 and 3510 (Fig. 1) (squares) and north arm density from the Salina station (Fig. 1) (circles). Arrows represent the periods of widespread deep brine layer

approximate balance. However from mid-2011 to 2013, dense north-to-south flow dominated (Fig. 9, 15a). Northto-south subsurface flow through the rock causeway was significant (at least $60 \mathrm{~m}^{3} / \mathrm{s}$ ) during the time that stratification became pronounced (Fig. 11). Interestingly, stratification persisted until 2014 despite decreases in both 
net culvert and subsurface causeway flux suggesting that residence time for the DBL may be significant even after the input of dense source water has ceased.

\section{Discussion}

As discussed above, north arm water conveyed to the south arm by the breach was minor during 2008-2015. Minor flow reversals through the breach (north-to-south rather than the dominant south-to-north) as a result of strong northerly wind events have been documented $[11,32]$ and suggested as a significant contributor to formation of the DBL in 2012 [32]. However, total north-tosouth flow through the breach constituted a very small percentage of total flow during the 2008-2015 period of low lake elevation (Fig. 12a, Table 3). Furthermore, the 1-m-thick DBL discussed by Naftz et al. [32] has a volume of approximately $0.12 \mathrm{~km}^{3}\left(1.2 \times 10^{8} \mathrm{~m}^{3}\right)$ as calculated from the hypsometric data of Baskin $[5,6]$. If flow reversal through the breach were the sole source of the deep brine layer, DBL residence times (volume divided by flux rates) would need to be on the order of years or decades. Interestingly, Jones and Wurtsbaugh [18] suggest a DBL residence time of 2.5 years.

It is important to recall that net subsurface causeway fluxes in this study (Fig. 14a, Table 3) are the sum of south-to-north and north-to-south flow. While the mass balance model does not compute absolute flux values, the net north-to-south flux during the first four months of 2012 (Fig. 15b; $0.40 \mathrm{~km}^{3}$ ) (Table 3) is more than adequate to replenish the DBL volume $\left(0.12 \mathrm{~km}^{3}\right)$ described for that year [32].

Comparing results of this mass balance model with the numerical model of Wold et al. [49] and Loving et al. [24] shows broad agreement but with considerable scatter at relatively low causeway fluxes (Fig. 16). At the higher south-to-north elevation gradients $(0.3-0.6 \mathrm{~m})$ during 2008-2015 net causeway flux of this mass balance model differs from that of Wold et al. [49] and Loving et al. [24]. While not encompassing the full range of causeway elevation gradients, the mass balance model suggests considerable lower subsurface causeway flux than the Wold/Loving model. Given the continued compaction and consolidation of the causeway material over the past 20 years, this is not necessarily surprising but it does suggest the numerical model needs updating.

It should be emphasized that the subsurface structure and permeability of the causeway have never been precisely characterized. Does the flow come through a small number of flow paths produced by piping in the 60-plus year-old causeway or is flow more widely dispersed? A detailed geophysical survey could address this

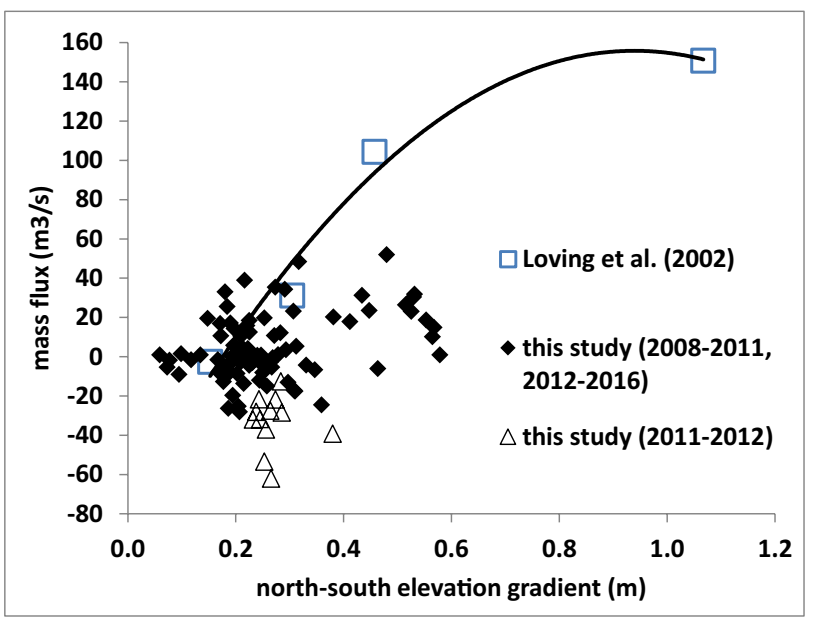

Fig. 16 Causeway elevation gradient versus net mass flux through the causeway. Solid line is taken from Table C-4 and C-5 of Loving et al. [24] assuming a north-south density gradient of $100 \mathrm{~kg} / \mathrm{m}^{3}$

issue and point the way toward a better understanding of the hydrologic regime of the lake as a whole.

The mass balance model might be used to evaluate a number of scenarios. A logical next step would be to analyze the effect of the new (2016) breach on lake fluxes. Doing so will require a viable model of net flux through the breach which is considerable larger than the breach used in this study. However, the lack of a gauge at the Bear River bridge could be a hindrance to application of the model of this study. Furthermore, the model might be used to forecast issues related to water diversions such as the proposed Bear River dam and climate change $[7,27]$ with attendant lowering levels of the Great Salt Lake and those throughout the world (e.g., [50].

\section{Conclusions}

(1) A mass balance model for an historic low stand of Great Salt Lake (2008-2015) demonstrates subsurface flux through the causeway was equal to or greater than culvert fluxes between the north and south arms of the lake.

(2) Subsurface flux through the causeway as a result of density differences between the north and south arms is a viable source for the Deep Brine Layer period over the entire south arm of the lake from late 2011 to early 2012 although causeway flux may or may not have been the driver for similar DBL episodes from the late 1990s to 2008. 
(3) Compaction of the rock causeway fill necessitates revision of earlier models of subsurface flow through the causeway.

Acknowledgements This work was supported by a FY 2015 grant from the Division of Forestry, Fire, and State Lands, State of Utah. Andrew Rupke (Utah Geological Survey) and Cory Angeroth (U.S. Geological Survey) kindly provided some of the data used in this research. Comments from Dr. Wayne Wurtsbaugh and two anonymous reviewers improved the manuscript.

\section{Declarations}

Conflict of interest The author states that there is no conflict of interest.

Open Access This article is licensed under a Creative Commons Attribution 4.0 International License, which permits use, sharing, adaptation, distribution and reproduction in any medium or format, as long as you give appropriate credit to the original author(s) and the source, provide a link to the Creative Commons licence, and indicate if changes were made. The images or other third party material in this article are included in the article's Creative Commons licence, unless indicated otherwise in a credit line to the material. If material is not included in the article's Creative Commons licence and your intended use is not permitted by statutory regulation or exceeds the permitted use, you will need to obtain permission directly from the copyright holder. To view a copy of this licence, visit http://creativecommons. org/licenses/by/4.0/.

\section{References}

1. Ackerman JT, Eagles-Smith CA, Herzog MP, Hartman CA, Peterson SH, Evers DC, Jackson AK, Elliott JE, Vander Pol SS, Bryan CE (2016) Avian mercury exposure and toxicological risk across western North America: a synthesis. Sci Tot Env 568:731-738. https://doi.org/10.1016/J.Scitotenv.2016.03.071

2. Aldrich TW, Paul DS (2002) Avian ecology of Great Salt Lake. In: Gwynn JW (ed) Great Salt Lake: an overview of change. Department of Natural Resources Special Publication, Utah, pp 343-385

3. Anderson RB, Naftz DL, Day-Lewis FD, Henderson R, Rosenberry DO, Jewell PW (2014) Quantity and quality of groundwater discharge in a hypersaline lake environment. J Hydrol 512:177-194. https://doi.org/10.1016/j.jhydrol.2014.02.040

4. Arnow T, Stephens D (1990) Hydrologic characteristics of the Great Salt Lake, Utah: 1847-1986. U.S.Geological Survey Water Supply Paper 2332

5. Baskin RL (2005) Calculation of area and volume for the south part of the Great Salt Lake, Utah. U. S. Geological Survey Open File Report 2005-1327

6. Baskin RL (2006) Calculation of area and volume for the north part of the Great Salt Lake, Utah. U. S. Geological Survey Open File Report 2006-1359

7. Baxter BK, Butler JK (2020) Climate change and Great Salt Lake. In: Baxter B, Butler J (eds) Great Salt Lake biology. Springer, Cham

8. Beisner K, Naftz DL, Johnson WP, Diaz X (2009) Selenium and trace element mobility affected by periodic displacement of stratification in the Great Salt Lake. SciTot Environ
407:5263-5273. https://doi.org/10.1016/j.scitotenv.2009.06. 005

9. Bioeconomics, Inc. (2012) Economic significance of the Great Salt Lake to the State of Utah: unpublished report for the Great Salt Lake Advisory Council

10. Daly C, Halbleib M, Smith JI, Gibson WP, Doggett MK, Taylor GH, Curtis J, Pasteris PP (2008) Physiographically sensitive mapping of climatological temperature and precipitation across the conterminous United States. J Climatol 28:20312064. https://doi.org/10.1002/joc.1688

11. Freeman ML (2014) Flow reversal events and statistical modeling of flow dynamics of hypersaline water across a constructed causeway, Great Salt Lake, Utah, U.S.A. M.S. thesis, University of Utah

12. Gillies RR, Chung OY, Wang SS, DeRose RJ, Sun Y (2015) Added value from 576 years of tree-ring records in the prediction of the Great Salt Lake level. J Hydrol 529:962-968

13. Gwynn JW (2002) Great Salt Lake, Utah: chemical and physical variations of the brine and effects of the SPRR causeway, 1966-1996. In: Gwynn JW (ed) Great Salt Lake: an overview of change. Utah Geological Survey Special Publication, Utah, pp 88-106

14. Gwynn, JW (2012). A lake divided-a history of the Southern Pacific Railroad causeway and its effect on Great Salt Lake, Utah. <http://geology.utah.gov/utahgeo/gsl/lakedivided.htm>.

15. Jellison R, Romero J, Melack JM (1998) The onset of meromixis in Mono Lake: unintended consequences of reducing water diversions. Limnol Oceanog 4:704-711

16. Jewell PW, Stallard RF, Mellor GL (1993) Numerical studies of bottom shear stress and sediment distribution on the Amazon continental shelf. J Sed Petrol 63:734-745

17. Johnson WP, Wurtsbaugh WA, Belovsky GD, Baxter BK, Black F, Angeroth C, Jewell PW, Yang S (2018) Geochemistry of Great Salt Lake. Science, Technology \& Society, Wiley Encyclopedia of Water, pp 1209-1225

18. Jones EF, Wurtsbaugh WA (2014) The Great Salt Lake's monimolimnion and its importance for mercury bioaccumulation in brine shrimp (Artemia franciscana). Limnol Oceanog 59:141-155

19. Kharaka Y, Robinson SW, Law LM, Carothers WW (1984) Hydrogeochemistry of Big Soda Lake, Nevada; an alkaline meromictic desert lake. Geochim Cosmochim Acta 48:823-835

20. Kim J (1973) Ecosystem of the Salton Sea. Geophys Monogr 17:601-605

21. Last WM, Vance RE (2002) The Holocene history of Oro Lake, one of the western Canada's longest continuous lacustrine records. Sed Geol 148:161-184

22. Last FM, Last WM (2012) Lacustrine carbonates of the northern Great Plains of Canada. Sed Geol 277-278:1-31

23. Lensky NG, Dvorkin Y, Lyahkovsky V (2005) Water, salt, and energy balances of the Dead Sea. Wat Resources Res 41:W12418

24. Loving BL, Waddell KW, Miller C, W, (2000) Water and salt balance of Great Salt Lake, Utah, and simulation of water and salt movement through the causeway. US Geol Survey Water Res Investig Rep 1987-98:2000-4221

25. Maszczyk P, Wurtsbaugh WA (2017) Brine shrimp grazing and fecal production increase sedimentation to the deep brine layer (monimolimnion) of Great Salt Lake, Utah. Hydrobiologia 802:7-22

26. Mao M, van der Westhuysen AJ, Meng X, Schwab DJ, Chawla A (2017) Modeling wind waves from deep to shallow waters in Lake Michigan using unstructured SWAN. J Geophys Res 121:3836-3865. https://doi.org/10.1002/2015JC011340

27. Meng Q (2019) Climate change and extreme weather drive the declines of saline lakes: a showcase of the Great Salt Lake. Climate $7(2): 19$ 
28. Mohammed IN, Tarboton DG (2012) An examination of the sensitivity of the Great Salt Lake to changes in inputs. Water Resources Res 48:w11511

29. Moon YI, Lall U (1996) Atmospheric flow indices and interannual Great Salt Lake variability. J Hydrologic Eng 1:55-62

30. Naftz DL, Angeroth C, Kenny T, Wadell B, Silva S, Darnall N, Perschon C, Whitehead J (2008) Anthropogenic influences on the input and biogeochemical cycling of nutrients and mercury in Great Salt Lake, Utah. Appl Geochem 23:1731-1744

31. Naftz DL, Millero FJ, Jones BF, Green WR (2011) An equation of state for hypersaline water in Great Salt Lake Utah. Aquatic Geochemi 17:809-820

32. Naftz DL, Carling GT, Angeroth $C$, Freeman $M$, Rowland $R$, Pazmino E (2014) Density-stratified flow events in Great Salt Lake, Utah, USA: Implications for mercury and salinity cycling. Aquatic Geochem 20:547-571

33. Oliver W, Fuller C, Naftz DL, Johnson WP, Diaz X (2009) Estimating selenium removal by sedimentation from the Great Salt Lake, Utah. Appl Geochem 24:936-949

34. Pinder GF, Cooper HH Jr (1970) A numerical technique for calculating the transient port of the salt-water front. Wat Resour Res 7:875-882

35. Pond S, Pickard GL (1983) Introductory dynamical oceanography. Pergamon Press, Oxford

36. Ravano CA., Dannelly P, Pita FW. (2008) The Great Salt Lake Causeway - Its Recent History and Current Maintenance Program. Proc. of AREMA Conference Proceedings. Jacobs Associates.

37. Reardon KE, Bombardelli FA, Moreno-Casas PA, Rueda FJ, Schladow SG (2014) Wind-driven nearshore sediment resuspension in a deep lake during winter. Wat Resour Res 50:8826-8844

38. Rush FE (1972) Hydrologic reconnaissance of Big and Little Soda Lakes, Churchill County, Nevada. Nevada Department of Conservation and Natural Resources

39. Sanford WE, Konikow LF (1985) A two-constituent solute transport model for ground water having variable density. US Geol Survey Water-Resour Investig Rep 85-4279:88

40. Scholl D., Ball, R., (2005) An evaluation of mercury concentrations in waterfowl from the Great Salt Lake. Utah Department of Health, Office Epidemiology, Environmental Epidemiology Program, Salt Lake City, Utah.

41. Seibt C, Peeters F, Graf M, Sprenger M, Hofmann H (2013) Modeling wind waves and wave exposure of nearshore zones in medium-sized lakes. Limnol Oceanog 58:23-36. https://doi.org/ 10.4319/lo.2013.58.1.0023
42. Sturm PA (1980) The Great Salt Lake brine system. In: Gwynn JW (ed) Great Salt Lake: a scientific, historical, and economic overview. Utah Geological and Mineral Survey Bulletin, Utah

43. Valdes C, Black FJ, Stringham B, Collins JN, Goodman JR, Saxton HJ, Mansfield CR, Schmidt JN, Yang S, Johnson JP (2017) Total mercury and methylmercury response in water, sediment, and biota to destratification of the Great Salt Lake, Utah, United States. Environ Sci Technol 51(9):4887-4896. https://doi.org/ 10.1021/acs.est.6b05790

44. Vest JL, Conover MR, Perschon C, Luft J, Hall JO (2009) Trace element concentrations in wintering waterfowl from the Great Salt Lake, Utah. Arch Environ Contam Toxicol 56:302-316

45. Wadell KM, Fields FK (1977) Model for evaluating the effects of dikes on the water and salt balance of Great Salt Lake. Utah Geol Min Surv Water Resour Bull 21:54

46. Wadell KM, Bloke EL (1973) The effects of restricted circulation on the salt balance of Great Salt Lake, Utah. Utah Geol Sur Water Resourc Bull 18:54

47. Wang SY, Gillies RR, Reichler T (2012) Multidecadal drought cycles in the Great Basin recorded by the Great Salt Lake: modulation from a transition-phase teleconnection. J Clim 25:1711-1721

48. White JS, Null S, Tarboton DG (2015) How do changes to the railroad causeway in Utah's Great Salt Lake affect water and salt flow? PLoS ONE 10(12):e0144111. https://doi.org/10.1371/journ al.pone. 0144111

49. Wold SR, Blakemore ET,Waddell KM, (1996) Water and salt balance of Great Salt Lake, Utah, and simulation of water and salt movement though the causeway: US Geological Survey Water Supply Paper 2450, $64 \mathrm{pp}$

50. Wurtsbaugh WA, Miller C, Null SE, DeRose RJ, Wilcock P, Hahnenberger M, Howe F, Moore J (2017) Decline of the world's saline lakes. Nat Geosci 10(11):816. https://doi.org/10.1038/ngeo3052

51. Yang S, Johnson WP, Black FJ, Rowland R, Rumsey C, Piskadlo A (2020) Response of density stratification, aquatic chemistry, and methylmercury to engineered and hydrologic forcings in an endorheic lake (Great Salt Lake, USA). Limnol Oceanogr 65:915-926

Publisher's Note Springer Nature remains neutral with regard to jurisdictional claims in published maps and institutional affiliations. 